\title{
SERUM COPPER LEVELS IN PREGNANCY AND IN PRE-ECLAMPSIA
}

\author{
BY \\ R. H. S. THOMPSON AND D. WATSON \\ From the Department of Chemical Pathology, Guy's Hospital Medical School, London
}

(RECEIVED FOR PUblication, MAY 19, 1949)

In $1928 \mathrm{Krebs}$ reported that the concentration of copper in the serum was significantly raised in the terminal stages of pregnancy. Since that time this observation has been confirmed by a number of workers (Gorter, Grendel, and Weyers, 1931 ; Locke, Main, and Rosbash, 1932 ; Sachs, Levine, and Fabian, 1935; Nielsen, 1944), who have shown that at full term the serum copper level is approximately twice the value found in non-pregnant subjects.

The significance of this raised serum copper level in pregnancy is, however, still obscure. Sachs, Levine, and Fabian (1935) have concluded that it represents a normal, physiological adjustment for the transport of copper from the maternal blood to the foetus, but no evidence is presented in support of this view. Other observations in the literature suggest that the hypercupraemia of pregnancy may, in part at least, be associated with some more specific function. It is well established that certain of the plant phenol oxidases are copper-containing proteins (Kubowitz, 1937, 1938 ; Keilin and Mann, 1938, 1939). Baker and Nelson (1943) have described a copper protein from kidney which is capable of catalysing the oxidation of adrenaline, and Holmberg in 1944 obtained, a blue coppercontaining protein from the "euglobulin" fraction of the serum proteins which possessed a laccase-like activity, catalysing the oxidation of p-phenylenediamine.

More recently, Holmberg and Laurell (1948) have described a blue protein containing $0.36 \% \mathrm{Cu}$ derived from the serum globulin fraction which, when added to male plasma to give a final copper concentration of $700 \mu \mathrm{g} . / 100 \mathrm{ml}$., increased the histaminolytic activity of the plasma 400 -fold. They also point out that the increase in serum copper in pregnancy runs parallel with the increase in the histaminolytic activity of the plasma.

In view of this finding, and since changes in the histaminolytic activity of the plasma have been reported in pre-eclamptic toxaemia (Kapeller-
Adler, 1944, 1947), a study of the level of serum copper in this condition has been carried out.

It is known from the work of Abderhalden and Möller (1928) and Boyden and Potter (1937) that the copper in the plasma from non-pregnant subjects exists in a non-dialysable form, and Eisler, Rosdahl, and Theorell (1936), using electrophoretic methods, have stated that the rate of migration of the copper in horse serum is the same as that of the serum albumin. Cohn and Koechlin (1947), on the other hand, have described a copper-combining protein in the $\beta$-globulin fraction of human plasma. Experiments have also been carried out therefore to determine the proportion of the copper precipitating with various protein fractions, separated by graded concentrations of sodium sulphate, from the serum of both non-pregnant and pregnant subjects.

\section{Experiments}

Materials.-Blood samples have been taken from 42 women with normal pregnancies (37-40 weeks), from 35 subjects four to seven weeks post-partum, from a further nine normal subjects at intervals throughout pregnancy, and from 18 healthy, nonpregnant women in the reproductive age.

Samples have also been obtained from 12 cases admitted to the maternity ward on account of preeclamptic toxaemia. The criteria on which this diagnosis was based were a blood pressure of over $160 / 90$ occurring after the thirtieth week of pregnancy in a subject whose blood pressure at the beginning of pregnancy had been within the normal range, together with either albuminuria (ten cases) or oedema (nine cases).

Methods. - The samples were taken into acid-cleaned all-glass syringes, and all glassware used subsequently in the course of the estimations was acid-cleaned and washed with copper-free water distilled over "pyrex" glass.

Copper was estimated in $3 \mathrm{ml}$. of the separated serum by a modification of the colorimetric method of Eden and Green (1940), based on the reaction of copper with sodium diethyldithiocarbamate. In all experiments in which it was desired to estimate the absolute 
amount of copper present, the sample was digested with $\mathrm{H}_{2} \mathrm{SO}_{4}, \mathrm{HNO}_{3}$, and $\mathrm{HClO}_{4}$; blank estimations were performed on identical amounts of all reagents used.

\section{Results}

The values obtained for the serum copper levels of a series of healthy, non-pregnant women, of women late in pregnancy (37-40 weeks), and of woren four weeks and five to seven weeks post-partum, together with a small series from cases of pre-eclamptic toxaemia, are shown in Table I.

TABLE I

Serum COPPER LeVels ( $\mu$ G.Cu/100 ML. SERUM) IN NoNpregnant Subjects, in Normal Pregnancy, and IN PRe-EClampsia

\begin{tabular}{c|c|c|c|c}
\hline Subjects & Mean & $\begin{array}{c}\text { Standard } \\
\text { Error of } \\
\text { the Mean }\end{array}$ & Range & $\begin{array}{c}\text { No. } \\
\text { of } \\
\text { Cases }\end{array}$ \\
\hline $\begin{array}{c}\text { Normal } \\
\text { Non-pregnant .. }\end{array}$ & 106 & 4.2 & $78-135$ & 18 \\
$\begin{array}{c}\text { Normal pregnancy } \\
\text { (37-40 weeks) }\end{array}$ & 230 & 5.7 & $180-288^{*}$ & 42 \\
$\begin{array}{c}\text { weeks post-par- } \\
\text { tum .. } \\
\text { 5-7 weeks post-par- } \\
\text { tum .. }\end{array}$ & 143 & 4.5 & $102-180$ & 24 \\
\hline Pre-eclamptic... & $277 \dagger$ & 5.4 & $88-139$ & 11 \\
\hline
\end{tabular}

- One value of 387 was obtained. Although this has been included in calculating the mean, it has not been included in the range since it differs from the mean by more than three times the standard it difiers from the mean

deviation of the mean

+ Individual values in pre-eclamptics were $250,312,255,337,275$, $277,235,281,252,283,285$, and $280 \mu \mathrm{g} . / 100 \mathrm{ml}$.

It will be seen that in each case the serum copper level in the terminal stages of normal pregnancy is very considerably raised.

A further nine cases attending the ante-natal clinic were followed through pregnancy at approximately three-monthly intervals, and a further estimation was made on each when the patient returned to hospital for the final post-natal examination. Since these subjects were attending the clinics as out-patients it was not possible in each case to obtain blood samples at exactly similar intervals, and the estimations were carried out at times varying from 10 to 16 weeks, 26 to 32 weeks, and 37 to 40 weeks of pregnancy in each case, and again at 6 to 11 weeks post-natally. The results of these estimations are given in Table II.

The findings of these nine cases confirm the earlier observations of Nielsen (1944) that the rise in serum copper occurs at an early stage in pregnancy; it will be seen that the level is significantly increased by the tenth to sixteenth week, although a further slight increase appears to take place until full term; 6 to 11 weeks after delivery the serum copper level appears to have returned once more to the normal level for the non-pregnant subject.
TABLE II

SERUM COPPER LEVELS ( $\mu$ G.CU/100 ML. SERUM) THROUGHout Normal Priegnancy and Post-natally

\begin{tabular}{|c|c|c|c|c|}
\hline Case & $\begin{array}{c}10-16 \\
\text { Weeks }\end{array}$ & $\begin{array}{l}26-32 \\
\text { Weeks }\end{array}$ & $\begin{array}{l}37-40 \\
\text { Weeks }\end{array}$ & $\begin{array}{c}\text { Post- } \\
\text { natal } \\
\text { (6-11 } \\
\text { Weeks) }\end{array}$ \\
\hline $\begin{array}{l}1 \\
2 \\
3 \\
4 \\
5 \\
6 \\
7 \\
8 \\
9\end{array}$ & $\begin{array}{l}267 \\
182 \\
193 \\
152 \\
182 \\
148 \\
166 \\
183 \\
179\end{array}$ & $\begin{array}{l}298 \\
-270 \\
178 \\
228 \\
190 \\
213 \\
225 \\
165\end{array}$ & $\begin{array}{c}288 \\
287 \\
228 \\
(387)^{*} \\
212 \\
240 \\
237 \\
240 \\
215\end{array}$ & $\begin{array}{r}185 \\
129 \\
89 \\
133 \\
126 \\
117 \\
95 \\
110 \\
92\end{array}$ \\
\hline Mean & 184 & 221 & 243 & 119 \\
\hline
\end{tabular}

* Not included in the mean given in this table since it differs from the mean given in Table $I$ by more than three times the standar deviation of the mean.

The values obtained in pre-eclampsia are also high the mean for the 12 cases studied being $277 \mu \mathrm{g} . / 100$ $\mathrm{ml}$. (standard error $=8.1$ ) compared with a mean of $230 \mu \mathrm{g} . / 100 \mathrm{ml}$. (s.e. = 5.7) for normal full-term preg nancies. Moreover, the standard error of the dif ference between these means is 11.5 giving $t=4$. for $n=52$. It should be pointed out that in calculating the standard error of the normal pregnant group the value of $387 \mu \mathrm{g} . / 100 \mathrm{ml}$. has been included in the series, even though this differed from the mean by more than three times the standard deviation of the mean.

From the results which we have obtained on this small series of cases it would appear that in pre eclampsia the serum copper level shows a small buㅗㅡ statistically significant increase over the normal eleva tion occurring in pregnancy.

In order to obtain information as to the physio logical significance of this extra serum copper in pregnancy it was decided to carry out some initial experiments to determine, by means of fractiona里 precipitation of the serum proteins, whether this excess copper in the serum behaves in a simila? fashion to the copper present in the serum of non N pregnant subjects, and also to obtain evidence as to which of the main groups of protein the copper is combined.

Total globulins were first precipitated with $26.8 \%$ $\mathrm{Na}_{2} \mathrm{SO}_{4}$ (Majoor, 1947 ; Milne, 1947), and the peres centage of the total serum copper precipitating with the globulins determined. In these fractionation ex periments advantage was taken of the finding by Tompsett (1934) that the serum copper can be quantio tatively estimated on trichloroacetic acid filtrates of whole serum, acidification releasing the copper frome its bound form. 
The globulins, precipitated from $3 \mathrm{ml}$. of serum by means of $26.8 \% \mathrm{Na}_{2} \mathrm{SO}_{4}$ (previously washed with ammoniacal sodium diethyldithiocarbamate, extracted with amyl alcohol, recrystallized and dried in the oven at $110^{\circ}$ C.), : were therefore dissolved in $\mathrm{H}_{2} \mathrm{O}$ and re-precipitated with a final concentration of $5 \%$ trichloroacetic acid; after standing for 10 minutes the precipitate was centrifuged, and the supernatant transferred to a separating cylinder for copper estimation. The precipitate was washed once with $3 \mathrm{ml} .5 \%$ trichloroacetic acid, and the supernatant also added to the separating cylinder. Total serum copper was estimated on the filtrate obtained by precipitation of $3 \mathrm{ml}$. serum with trichloroacetic acid in the same manner.

In addition, Milne (1947) has shown that $19.6 \%$ $\mathrm{Na}_{2} \mathrm{SO}_{4}$ yields a precipitate of "euglobulin" which appears to correspond reasonably quantitatively with electrophoretically estimated $\beta-+\gamma$-globulins, and Kibrick and Blonstein (1948) have claimed that a fraction agreeing satisfactorily with electrophoretically estimated $\gamma$-globulin can be obtained by precipitation with $15 \% \mathrm{Na}_{2} \mathrm{SO}_{4}$. An attempt was made therefore to estimate the copper in fractions precipitated with $15 \%, 19.6 \%$, and $26.8 \% \mathrm{Na}_{2} \mathrm{SO}_{4}$ in the hope of being able thereby to determine roughly the percentage of the total serum copper bound with the $a-, \beta-$, and $\gamma$-globulin fractions respectively. Some difficulty was experienced, however, in obtaining satisfactory flocculation for either filtration or centrifugation of the precipitates obtained at these salt concentrations without the use of high dilutions of the serum which would have introduced inaccuracies into the subsequent copper estimations. For this reason ether was added in order to obtain a compact and centrifugable separation of the precipitated globulins (Kingsley, 1940).

The procedure finally adopted was as follows: Serum, $3 \mathrm{ml}$., is added slowly to the weighed quantity of solid copper-free $\mathrm{Na}_{2} \mathrm{SO}_{4}$ contained in a roundbottomed centrifuge-tube which is stirred mechanically and immersed in a water-bath at $35^{\circ} \mathrm{C}$. After stirring for five minutes the tube is removed from the bath, $1 \mathrm{ml}$. of ether added, and the tube shaken for 20 to 30 seconds. It is then immediately centrifuged for 10 minutes at 3,000 revolutions per minute. The ether is then poured off, and the lower aqueous layer removed with a teat-ended capillary pipette and discarded. The precipitate is dissolved in $4 \mathrm{ml}$. of water and re-precipitated with trichloroacetic acid as described above.

The percentages of the total serum copper precipitating with the various globulin fractions obtained by these means are shown in Table III. Using only $\mathrm{Na}_{2} \mathrm{SO}_{4}$ as the precipitating agent it will be seen that $89 \%$ of the copper present in the serum from nonpregnant subjects appears in the precipitate of total globulins ; when $\mathrm{Na}_{2} \mathrm{SO}_{4}$ together with ether was used, the globulin precipitate contained $86 \%$ of the total copper present in the serum, a value not differing significantly from that obtained with $\mathrm{Na}_{2} \mathrm{SO}_{4}$ alone. $A$ few experiments were also done to compare the effects of the use of ether on the fractions precipita- ting with $15 \%$ and $19.6 \% \mathrm{Na}_{2} \mathrm{SO}_{4}$, but again it was found that the presence of ether did not affect the amount of copper precipitating at these concentrations. Although no electrophoretic study of these protein fractions has been made, it has therefore been concluded that we may justifiably consider these fractions as representing roughly the $\alpha-, \beta$-, and $\gamma$-globulin fractions described by Kibrick and Blonstein (1948).

TABLE III

Percentages of Total Serum Copper Precipitating with. Varying Globulin Fractions

\begin{tabular}{|c|c|c|c|c|}
\hline Subjects & \multicolumn{4}{|c|}{ Precipitant } \\
\hline & \multicolumn{3}{|c|}{$\begin{array}{c}\mathrm{Na}_{2} \mathrm{SO}_{4}(\%) \\
+ \text { Ether }\end{array}$} & \multirow{2}{*}{ 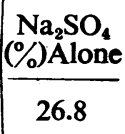 } \\
\hline & 15 & 19.6 & 26.8 & \\
\hline Normal, non-pregnant & $\begin{array}{l}33 \\
21 \\
38 \\
16 \\
23\end{array}$ & $\begin{array}{l}82 \\
79 \\
74 \\
81 \\
68\end{array}$ & $\begin{array}{l}75 \\
97 \\
85 \\
86 \\
89\end{array}$ & $\begin{array}{l}94 \\
95 \\
86 \\
86 \\
86\end{array}$ \\
\hline Mean $\%$ of copper $\quad \ldots$ & 26 & 77 & 86 & 89 \\
\hline Pregnant (37-40 weeks) & $\begin{array}{l}31 \\
29 \\
22 \\
22 \\
25 \\
24 \\
22\end{array}$ & $\begin{array}{l}84 \\
81 \\
80 \\
76 \\
81 \\
- \\
-\end{array}$ & $\begin{array}{r}98 \\
94 \\
100 \\
85 \\
100 \\
86 \\
90\end{array}$ & \\
\hline Mean $\%$ of copper & 25 & 80 & 93 & \\
\hline
\end{tabular}

The results summarized in Table III show that no significant difference exists between non-pregnant and pregnant sera as regards the amount of copper appearing in the protein fractions precipitated by $15 \%$, $19.6 \%$, and $26.8 \% \mathrm{Na}_{2} \mathrm{SO}_{4}$. Further, using Kibrick and Blonstein's interpretation of these protein fractions, it appears that approximately $25 \%$ of the copper is combined with the $\gamma$-globulin fraction, $55 \%$ with the $\beta$-globulins, and a further $10 \%$ with the a-globulins.

\section{Discussion}

The considerable increase in the serum copper level in pregnancy observed by earlier workers has been confirmed. The main object of the present work was to discover whether this elevated serum copper level undergoes any change if a preeclamptic toxaemia develops in the course of the pregnancy. Although the number of cases of preeclamptic toxaemia which we have been able to study is small, the results show that in this condition there appears to be a small but statistically significant increase in the serum copper level over 
the normal elevation which occurs in a healthy pregnancy. From the few cases we have studied there does not appear to be any obvious evidence of a correlation between the severity of the toxaemia and the height of the serum copper level, although further work on a larger series of cases would be needed to establish this point. It is clear, however, that the decrease in histaminolytic activity of the plasma in pre-eclamptic toxaemias, which has been reported by Kapeller-Adler (1944, 1947), is not accompanied by any corresponding fall in the level of serum copper.

With a view to obtaining information about the state and physiological significance of the raised serum copper in pregnancy, information has been obtained as to relative amounts of copper bound to the various fractions of the plasma proteins. Our finding that $90 \%$ of the serum copper appears in the globulin precipitate produced by $26.8 \%$ $\mathrm{Na}_{2} \mathrm{SO}_{4}$ agrees well with the proportion precipitated by $50 \%$ saturation with $\left(\mathrm{NH}_{4}\right)_{2} \mathrm{SO}_{4}$ (Holmberg and Laurell, 1947). By using graded concentrations of $\mathrm{Na}_{2} \mathrm{SO}_{4}$ it has been shown that the greater part of this globulin-bound copper exists in combination with those globulins precipitating between $15 \%$ and $19.6 \% \mathrm{Na}_{2} \mathrm{SO}_{4}$, that is with a fraction which has been claimed by Kibrick and Blonstein (1948) to consist largely of $\beta$-globulins. In this connexion it is of interest that Longsworth, Curtis, and Pembroke (1945) have shown by electrophoretic analysis that in pregnancy there is a decrease in the serum albumin level accompanied by an approximately two-fold increase in the $\beta$-globulin level. Novak and Lustig (1947) have also reported a significant fall in the albumin/ globulin ratio of the serum in pregnancy, and have claimed that this ratio is still further reduced in toxaemic patients, a finding which accords with our demonstration of a further rise in the serum copper level in pre-eclamptic toxaemias. Moreover, a $\beta$-globulin has recently been isolated from human plasma which is capable of combining with iron, copper, or zinc, and has been designated the "metal-combining globulin" (Cohn and Koechlin, 1947 ; Surgenor, Koechlin, and Strong, 1949). The properties of this metal-combining protein have so far mainly been studied in connexion with its combination with iron. Although the present findings are not concerned specifically with this protein, they indicate that not only does the larger part of the copper normally present in human serum also exist in combination with a $\beta$-globulin, but that the extra copper present during pregnancy appears to show the same distribution among the major fractions of the plasma proteins. Our results with human serum are therefore in con-을 trast with the findings of Eisler, Rosdahl, and $\Rightarrow$ Theorell (1936) that the copper in horse serum is? largely associated with the albumin fraction.

\section{Summary}

Estimations of the serum copper level have been carried out in .blood samples obtained from ${ }^{\infty}$ healthy, non-pregnant women, from women late. in pregnancy, from women four to eleven weeks $\overrightarrow{\vec{H}}$ post-partum, and in 12 cases of pre-eclamptic toxaemia.

The results indicate that in pre-eclampsia the serum copper level shows a small but significantiv increase over the normal elevation occurring in $\overrightarrow{0}$ pregnancy.

Approximately $90 \%$ of the serum copper appears $\bigcirc$ in the globulin precipitate produced by $26.8 \%$ $\mathrm{Na}_{2} \mathrm{SO}_{4}$.

By the use of graded concentrations of $\mathrm{Na}_{2} \mathrm{SO}_{4}$ the copper partition among various globulin frac-? tions has been determined.

No significant difference was observed betweenct samples from pregnant and non-pregnant subjectso in the distribution of the protein-bound copper.

We should like to acknowledge gratefully the helpo given to us in the collection of samples from pregnant subjects by Mr. J. B. Blaikley, F.R.C.S., $\stackrel{\mathcal{Q}}{\varrho}$ F.R.C.O.G., and the staff of the Department of $\overrightarrow{0}$ Obstetrics and Gynaecology, Guy's Hospital Medical 3 School, London.

\section{REFERENCES}

Abderhałden, E., and Möller, P. (1928). Hoppe-Seyl. Z., 176, 95. Baker, D., and Nelson, J. M. (1943). J. biol. Chem., 147, 341 .

Boyden, R., and Potter, V. R. (1937). J. biol. Chem., 122, 285.

Cohn, E. J., and Koechlin, B. A. (1947). Abstr. Amer. Chem. Soc. 112th meeting, $30 \mathrm{C}$.

Eden, A., and Green, H. H. (1940). Biochem. J., 34, 1202.

Eisler, B., Rosdahl, K. G.; and Theorell, H. (1936). Biochem. Z., 286, 435 Gorter, E., Grendel, F., and Weyers, W. A. M. (1931). 'Rev. franc.

Holmberg, C. G. (1944). Acta physiol. scand., 8, 227.

Holmberg, C. G., and Laurell, C. B. (1947). Acta chem. scand., 1, $944 . \frac{1}{2}$

Holmberg, C. G., and Laurell, C. B. (1948). Nature, Lond., 161, 236.

Kapeller-Adler, R. (1944). Biochem. J., 38, 270.

Kapeller-Adler, R. (1947). Prec. XVIII Internat. Physiol. Congr., p. 356.

Keilin, D., and Mann, T. (1938). Proc. roy. Soc. B., 125, 187.

Keilin, D., and Mann, T. (1939). Nature, Lond., 143, 23.

Kibrick, A. C., and Blonstein, M. (1948). J. biol. Chem., 176, 983.

Kingsley, G. R. (1940). J. biol. Chem., 133, 731 .

Krebs, H. A. (1928). Klin. Wschr., 7, 584 .

Kubowitz, F. (1937). Biochem. Z., 292, 221.

Kubowitz, F. (1938). Biochem. Z., 299, 32. (1932). J. clin. Invest.,

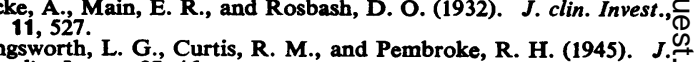

ongsworth, L. G., Curtis, R. M., and Pembroke,
clin. Invest., 25, 46.
Majoor, C. L. H. (1947). J. biol. Chem., 168, 583.

Majoor, C. L. H. (1947). J. biol. Chem., 198

Nielsen, A. L. (1944). Acta med. scand., 118, 84.

Novak, J., and Lustig, B. (1947). J. Mt Sinai Hosp. 14, 534.

Sachs, A., Levine, V. E., and Fabian, A. A. (1935). Arch. intern. $\frac{\overbrace{1}}{Q}$

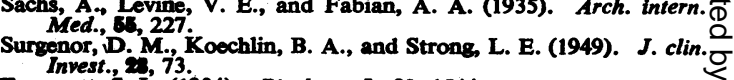

Tompsett, S. L. (1934). Biochem. J., 23, 1544. 